\title{
PENGARUH LIKUIDITAS, LEVERAGE, MANAJEMEN LABA, KOMISARIS INDEPENDEN DAN UKURAN PERUSAHAAN TERHADAP AGRESIVITAS PAJAK
}

\author{
Irvan Tiaras dan Henryanto Wijaya \\ Fakultas Ekonomi Universitas Tarumanagara Jakarta \\ Email: henryanto_wijaya@yahoo.com
}

\begin{abstract}
The purpose of this research is to analyze the effect of liquidity, leverage, earnings management, proportion of independent commissioner, and firm size on the level of company tax aggressiveness. This research uses manufacturing industries listed on Bursa Efek Indonesia in 2010-2011 as the population. Using purposive sampling technique, 148 data are selected as samples. The result of multiple regression analysis shows that the impact of earnings management and firm size on the level of company tax aggressiveness is significant. Therefore liquidity, leverage, and proportion of independent commissioner show no significant effect on the level of corporate tax aggressiveness.
\end{abstract}

Key words: Analyze, effect of liquidity, leverage, earnings management, independent commissioner

\begin{abstract}
Abstrak: Tujuan dari penelitian ini adalah menganalisa pengaruh likuiditas, leverage, manajemen laba, proporsi komisaris independen, dan ukuran perusahaan terhadap tingkat agresivitas pajak perusahaan. Penelitian ini menggunakan industri manufaktur yang terdaftar di Bursa Efek Indonesia tahun 2010-2011 sebagai populasi. Dengan menggunakan teknik purposive sampling, 148 data terpilih sebagai sampel. Hasil analisis regresi berganda menunjukan bahwa manjamen laba dan ukuran perusahaan memiliki pengaruh yang signifikan terhadap tingkat agresivitas pajak perusahaan. Sementara untuk likuiditas, leverage, dan proporsi komisaris independen tidak menunjukan pengaruh yang signifikan terhadap tingkat agresivitas pajak perusahaan.
\end{abstract}

Kata kunci: Analisis, pengaruh likuiditas, leverage, komisaris independen

\section{PENDAHULUAN}

Pajak merupakan salah satu sumber penerimaan negara yang sangat penting di Indonesia. Hal ini tercermin dari komposisi penerimaan pajak negara dalam Anggaran Pendapatan dan Belanja Negara. Penerimaan pajak negara memiliki persentase terbesar dari total penerimaan negara secara keseluruhan. Realisasi penerimaan pajak negara dari tahun 2007 sampai tahun 2011 mengalami peningkatan secara berkesinambungan. Penerimaan negara tahun 2007 sebesar 69,37\% dari total penerimaan negara atau setara dengan Rp 490,988.7 milyar. Tahun 2008 total penerimaan negara adalah sebesar Rp 981,609 milyar, 67,10\% di antaranya adalah penerimaan pajak. Peningkatan pada tahun 2009 dimana 73,04\% penerimaan negara berasal dari penerimaan pajak dari total Rp 848,763.4 milyar 
penerimaan negara. Demikian juga tahun 2010 dan 2011 dimana penerimaan pajak sebesar 72,67\% dan 72,19\% dari total penerimaan negara.

Perusahaan yang merupakan wajib pajak, menganggap bahwa pajak merupakan beban yang akan mengurangi keuntungan perusahaan. Hal tersebut mendorong perusahaan untuk mencari cara mengurangi beban pajak. Oleh karena itu, sangat dimungkinkan perusahaan menjadi agresif dalam perpajakan (Suyanto et al, 2012). Menurut Frank dalam Suyanto et al (2012), agresivitas pajak perusahaan adalah suatu tindakan merekayasa pendapatan kena pajak yang dilakukan perusahaan baik dengan cara yang legal (tax avoidance) maupun dengan cara ilegal (tax evasion).

Banyak penelitian yang telah dilakukan untuk meneliti faktor-faktor apa saja yang mempengaruhi tingkat agresivitas pajak. Di Indonesia, Suyanto dan Supramono (2012) serta Annisa dan Kurniasih (2012) melakukan penelitian mengenai tindakan pajak agresif yang dilakukan oleh perusahaan. Lebih banyak lagi, penelitian di luar negeri mengenai perilaku pajak agresif perusahaan dilakukan oleh Liu dan Cao (2007), Hsieh (2012), Richardson dan Lanis (2007), dan lain sebagainya.

Salah satu faktor yang menjadi perhatian penelitian sebelumnya adalah tingkat likuiditas perusahaan. Penelitian yang dilakukan oleh Bradley (1994) serta Siahaan (2005), dalam Suyanto dan Supramono (2012), menemukan bahwa perusahaan dengan tingkat likuiditas yang baik cenderung lebih taat terhadap kewajiban perpajakannya. Sementara itu temuan Suyanto dan Supramono (2012) mengungkapkan bahwa tidak ada pengaruh signifikan antara likuiditas dan perilaku pajak agresif perusahaan.

Setiawan (2006), dalam Suyanto dan Supramono (2012), menyebutkan bahwa sejalan dengan peningkatan leverage, tingkat agresivitas pajak juga ikut dipengaruhi dengan signifikan. Hal yang berbeda diungkapkan oleh Richardson dan Lanis (2007) yang menyatakan bahwa leverage perusahaan tidak mempengaruhi agresivitas pajak perusahaan.

Manajemen laba juga dikaitkan terhadap perilaku agresif pajak perusahaan. Scott (2000), dalam Suyanto dan Supramono (2012),menyatakan bahwa salah satu motivasi manajemen melakukan manajemen laba adalah motivasi perpajakan. Hal ini dapat dijelaskan karena dasar pengenaan pajak adalah jumlah penghasilan kena pajak yang dilaporkan oleh perusahaan maka perusahaan cenderung menjaga labanya pada level tertentu. Sehingga dapat diprediksikan bahwa perusahaan dengan tingkat pendapatan yang cenderung meningkat akan melakukan income decreasing. Sebaliknya, perusahaan dengan tingkat pendapatan yang cenderung menurun diprediksikan akan melakukan income increasing untuk menghindari pemeriksaan pajak karena melaporkan kerugian. Lee dan Swenson (2011) menyatakan hal yang sebaliknya, bahwa efek perpajakan tidak dipengaruhi oleh kegiatan manajemen laba.

Penelitian Lanis dan Richardson (2011) menyatakan bahwa proporsi komisaris independen berpengaruh negatif terhadap tingkat agresivitas pajak. Dengan demikian kehadiran komisaris independen dapat menekan perilaku pajak agresif perusahaan. Hal ini berbeda dengan temuan Annisa dan Kurniasih (2012) yang menyatakan bahwa agresivitas pajak tidak dipengaruhi oleh proporsi komisaris independen melainkan oleh faktor lainnya seperti kepemilikan institusional, keberadaan komite audit, dan kualitas audit.

Hasil penelitian Liu dan Cau (2007) menunjukkan bahwa ukuran perusahaan tidak berdampak signifikan terhadap tingkat agresivitas pajak. Di lain pihak, beberapa peneliti, 
seperti Lanis dan Richardson (2007) menemukan bahwa ukuran perusahaan berbanding lurus dengan tindakan pajak agresif.

Penelitian ini bermaksud mengintegrasikan beberapa penelitian yang telah ada sebelumnya serta menganalisis kembali pengaruh yang ditimbulkan antara likuiditas, leverage, manajemen laba, proporsi komisaris independen dan ukuran perusahaan terhadap agresivitas pajak perusahaan. Penelitian ini berbeda dengan penelitian terdahulu karena sampel yang digunakan adalah perusahaan manufaktur yang terdaftar di Bursa Efek Indonesia selama periode 2010 hingga 2011.

\section{KAJIAN TEORI}

Likuiditas. Subramanyam dan Wild (2010:241) mendefinisikan likuidias sebagai kemampuan perusahaan untuk memenuhi kewajiban jangka pendeknya yang secara konvensional, 'jangka pendek' dianggap periode hingga satu tahun meskipun dikaitkan dengan siklus operasional normal perusahaan. Dengan demikian likuiditas sangat penting bagi sebuah perusahaan. Likuiditas dapat digunakan untuk memperhitungkan dampak yang berasal dari ketidakmampuan perusahaan memenuhi kewajiban jangka pendeknya. Dalam kaitannya dengan pajak, Suyanto dan Supramono (2010) menyatakan bahwa likuiditas sebuah perusahaan diprediksi akan mempengaruhi agresivitas pajak perusahaan. Perusahaan yang memiliki likuiditas tinggi menggambarkan arus kas yang baik sehingga perusahaan tersbut tidak enggan untuk membayar seluruh kewajibannya termasuk membayar pajak sesuai peraturan yang berlaku. Senada dengan hal tersebut Bradley dan Siahaan (dalam Suyanto dan Supramono, 2010) yang menemukan bahwa perusahaan yang memiliki arus kas yang rendah akan tidak taat terhadap pajak guna mempertahankan arus kas perusahaan dari pada harus membayar pajak.

H1 : Likuiditas memiliki pengaruh yang signifikan terhadap tingkat agresivitas pajak perusahaan

Leverage. Leverage adalah ukuran persentase total aset perusahaan yang diperoleh dari pihak kreditur (Kieso et al, 2009:796). Mills (dalam Dunbar, 2011) berpendapat bahwa leverage mencerminkan kompleksitas transaksi keuangan perusahaan. Sehingga perusahaan dengan tingkat leverage yang tinggi memiliki kemampuan yang lebih untuk menghindari pajak melalui transaksi-transaksi keuangan. Graham dan Tucker (dalam Dunbar, 2011) menyatakan bahwa perusahaan dengan tingkat leverage yang lebih tinggi kurang membutuhkan tax shield yang tidak berasal dari utang sehingga mengurangi perilaku pajak agresif.

H2 : Leverage memiliki pengaruh yang signifikan terhadap tingkat agresivitas pajak perusahaan

Manajemen Laba. Pada dasarnya, definisi operasional dari manajemen laba adalah potensi penggunaan manajemen akrual dengan tujuan memperoleh keuntungan pribadi (Belkoui, 2007:201). Schipper (dalam Lee dan Swenson, 2011) mendefinisikan manajemen laba sebagai “. . . . purposeful intervention in the external financial reporting process, with the intent of obtaining some form of private gain.” Sementara Cohen dan Zarowin (dalam Lee dan Swenson, 2011) mendefinisikan manajemen laba sebagai “... . 
firms manage earnings through real activities manipulation as well through accruals ... ."

Definisi-definisi diatas memberikan gambaran bahwa manajemen laba adalah suatu usaha yang dilakukan oleh perusahaan untuk memperoleh besarnya laba atau pendapatan sesuai dengan keinginan dan tujuan yang ingin dicapai oleh perusahaan. Sesuai kutipankutipan di atas, manajemen laba tersebut dapat dilakukan melalui aktivitas perusahaan sesungguhnya maupun memanfaatkan rekening akrual perusahaan.

H3 : Manajemen laba memiliki pengaruh yang signifikan terhadap tingkat agresivitas pajak perusahaan

Proporsi Komisaris Independen. Sesuai dengan Peraturan Nomor IX.I.5 Lampiran Keputusan Ketua BAPEPAM Kep-41/PM/2003, komisaris independen adalah anggota komisaris yang (1) berasal dari luar emiten atau perusahaan publik, (2) tidak mempunyai saham baik langsung maupun tidak langsung pada emiten atau perusahaan publik, (3) tidak mempunyai hubungan afiliasi dengan emiten atau perusahaan publik, komisaris, direksi, atau pemegang saham utama emiten atau perusahaan publik, dan (4) tidak memiliki hubungan usaha baik langsung maupun tidak langsung yang berkaitan dengan kegiatan usaha emiten atau perusahaan publik.

Terkait dengan proporsi komisaris independen, Keputusan Direksi PT Bursa Efek Jakarta Nomor Kep-305/BEJ/07-2004 mengharuskan perusahaan tercatat memiliki komisaris independen sekurang-kurangnya 30\% dari jajaran anggota Dewan Komisaris. Kehadiran komisaris independen juga diprediksi akan mempengaruhi agresivitas pajak perusahaan. Menurut Fama \& Jensen (dalam Suyanto dan Supramono, 2010) semakin banyak komisaris independen maka pengawasan terhadap kinerja manajer dianggap lebih efektif. Dengan adanya pengawasan yang ketat dari komisaris independen maka akan mengurangi kesempatan manajer untuk berlaku agresif terhadap pajak perusahaan. Manajer melakukan agresivitas pajak perusahaan karena adanya kepentingan untuk meningkatkan laba perusahaan dengan cara mengurangi beban perusahaan termasuk beban pajak.

H4 : Proporsi komisaris independen memiliki pengaruh yang signifikan terhadap tingkat agresivitas pajak perusahaan

Ukuran Perusahaan. Ukuran perusahaan dan tingkat agresivitas pajak merupakan hal yang menarik perhatian para peneliti. Hal ini terlihat dari banyaknya penelitian yang dilakukan terkait dengan interaksi antara kedua variabel ini, seperti Zimmerman (1983), Lanis dan Richardson (2007), Liu dan Cao (2007), dan Hsieh (2012). Mengenai hubungan antara ukuran perusahaan dan tingkat agresivitas pajak, terdapat ketidakkonsistenan hasil penelitian. Liu dan Cao (2009:51) menuliskan:

". . . . The work by Zimmerman (1983) suggests that larger firms may have fewer tax preferences available than smaller firms because large firms receive more attention from the public and stricter regulation from the government (that is, large political costs are borne by large firms). This is the so-called political cost hypothesis of positive effects of firm size on ETR. However, some studies (for example, Porcano 1986) found a negative effect of firm size on ETR, which is called political right hypothesis. The theoretical prediction of this hypothesis is that large firms have more resources to lobby and hire professionals to gain tax 
avoidance, thus they bear a lower tax burden or lower ETR. Recent evidence from Shelvin and Porter (1992) and Manzon and Smith (1994) is consistent with Stickney and McGee (1982), supporting the theoretical claim that there is no significant relationship between firm size and ETR. ....”

Kutipan tersebut menunjukkan bahwa kesenjangan penelitian tentang kedua variabel ini telah berlangsung lama.

H5 : Ukuran perusahaan memiliki pengaruh yang signifikan terhadap tingkat agresivitas pajak perusahaan

\section{METODE}

Teknik pengambilan sampel yang digunakan dalam penelitian ini adalah purposive sampling. Purposive sampling adalah "a nonprobability sample that conforms to certain criteria” (Cooper dan Schindler, 2011:385). Kriteria seleksi sampel yang digunakan dalam model penelitian adalah: (a) perusahaan secara konsisten terdaftar di Bursa Efek Indonesia tahun 2010 dan tahun 2011; (b) perusahaan menerbitkan laporan keuangan lengkap dimana dapat diperoleh data yang dibutuhkan dalam penelitian ini; (c) perusahaan menggunakan mata uang Rupiah dan menggunakan tahun buku 1 Januari sampai dengan 31 Desember untuk meningkatkan komparabilitas dalam penelitian; (d) memperoleh pendapatan dari kegiatan operasional untuk tahun 2009, 2010 dan 2011 untuk mengoptimalkan pengukuran dalam penelitian; (e) perusahaan tidak mengalami kerugian sebelum pajak karena dasar pengenaan pajak penghasilan adalah Income Before tax; (f) perusahaan tidak mengalami kerugian setelah pajak, karena kerugian setelah beban pajak penghasilan berarti perusahaan memiliki effective tax rate lebih besar dari 1 dan hal tersebut akan mendistorsi penelitian; (g) perusahaan tidak memperoleh income tax benefits, karena income tax benefits akan mendistorsi penelitian; (h) data komisaris independen tersedia dan dapat ditentukan dalam dalam persentase.

Operasionalisasi variabel-variabel yang digunakan dalam penelitian ini adalah sebagai berikut.

a. Rasio Likuiditas. Likuiditas didefinisikan sebagai ukuran dalam menilai kemampuan sebuah perusahaan untuk memenuhi kewajiban jangka pendek dan kemampuan perusahaan dalam menghadapi kondisi mendesak yang memerlukan dana (Kieso et al, 2009:788). Rasio likuiditas diukur dengan :

$$
\text { Likuiditas }=\frac{\text { Asset Lancar }}{\text { Kewajiban Lancar }}
$$

b. Rasio Leverage. Leverage didefinisikan sebagai besarnya persentase aset yang diperoleh melalui hutang. Rasio ini mengindikasikan kemampuan perusahaan untuk menanggung kerugian usahanya tanpa mengganggu kepentingan pihak kreditur (Kieso et al, 2009:796). Rasio leverage diukur dengan:

$$
\text { Leverage }=\frac{\text { Total Debt }}{\text { Total Assets }}
$$

c. Manajemen Laba. Manajemen laba pada penelitian ini adalah manajemen laba yang diukur dengan menggunakan discretionary accruals. Discretionary accruals dihitung 
dengan cara menyelisihkan total accruals dan non discretionary accruals. Dalam menghitung discretionary accruals digunakan Modified Jones Model. Model perhitungannya adalah sebagai berikut:

$$
T A_{\text {it }}=N I_{\text {it }}-C F O_{\text {it }}
$$

Nilai total accruals diestimasi dengan persamaan regresi Ordinary Least Square sebagai berikut:

$$
\frac{T A_{\text {it }}}{A_{\text {it }-1}}=\beta_{1}\left(\frac{1}{A_{\text {it }-1}}\right)+\beta_{2}\left(\frac{\Delta \operatorname{Rev}_{\text {it }}}{A_{\text {it }-1}}\right)+\beta_{2}\left(\frac{\text { PPE }_{\text {it }}}{A_{\text {it }-1}}\right)+\varepsilon
$$

Dengan menggunakan koefisien regresi di atas nilai non discretionary accruals (NDA) dapat dihitung dengan rumus:

$$
\frac{N D A_{\text {it }}}{A_{\text {it }-1}}=\beta_{1}\left(\frac{1}{A_{\text {it }-1}}\right)+\beta_{2}\left(\frac{\Delta \operatorname{Rev}_{\text {it }}}{A_{\text {it }-1}}-\frac{\Delta A R_{\text {it }}}{A_{\text {it }-1}}\right)+\beta_{1}\left(\frac{P P E_{\text {it }}}{A_{\text {it }-1}}\right)+\varepsilon
$$

Selanjutnya discretionary accruals (DA) dapat dihitung sebagai berikut:

\begin{tabular}{|c|c|}
\hline $\begin{array}{l}\mathrm{DA}_{\mathrm{i}} \quad=\text { discretionary } \\
\text { perusahaan } i \text { pada periode ke } t\end{array}$ & $\begin{array}{l}A_{\mathrm{in}-1} \quad=\text { total assets perusahaan } i \\
\text { pada periode ke } t-1\end{array}$ \\
\hline $\begin{array}{l}\mathbb{B D A}_{\mathrm{i}}=\text { non-discretionary accruals } \\
\text { perusahaan } i \text { pada periode ke } t\end{array}$ & $\begin{array}{l}\mathbb{A R} w_{i x} \quad \text { perubahan } \\
\text { perusahaan } i \text { pada periode } t\end{array}$ \\
\hline $\begin{array}{l}\mathbb{V A}_{\mathrm{i}} \quad=\text { total accruals perusahaan } i \\
\text { pada periode ke } t\end{array}$ & $\begin{array}{l}P^{\prime}=\text { aktiva tetap perusahaan } i \\
\text { pada periode } t\end{array}$ \\
\hline $\begin{array}{l}\quad=\text { net income perusahaan } i \\
\text { pada periode ke } t\end{array}$ & $\begin{array}{l}\operatorname{ARR}_{\mathrm{at}} \quad \text { perubahan piutang } \\
\text { perusahaan } i \text { pada periode } t\end{array}$ \\
\hline $\begin{array}{l}=\text { cash flow from operating } \\
\text { activities perusahaan } i \text { pada }\end{array}$ & $\begin{array}{ll}\mathbb{R}_{2-\pi} & =\text { koefisien regresi } \\
\mathbb{E} & =\text { error terms }\end{array}$ \\
\hline
\end{tabular}

Keterangan:

$$
D A_{\text {it }}=\frac{N A_{\text {it }}}{A_{\text {it }-1}}-N D A_{\text {it }}
$$

d. Proporsi Komisaris Independen. Proporsi dewan komisaris independen diukur dengan menggunakan indikator persentase anggota dewan komisaris yang berasal dari luar perusahaan dari seluruh ukuran anggota dewan komisaris perusahaan (Liu dan Cao, 2007).

$$
\text { Proporsi Komisaris Independen }=\frac{\text { Jumlah Komisaris Independen }}{\text { Total Dewan Komisaris }}
$$

e. Ukuran Perusahaan. Ukuran perusahaan diukur dengan logaritma natural dari total asset yang dimiliki perusahaan pada akhir tahun (Liu dan Cao, 2007:57).

$$
\text { Ukuran Perusahaan }=\text { Ln(Total Asset })
$$

f. Tingkat Agresivitas Pajak. Beberapa penelitian sebelumnya (Chen et al., 2010; Martani, 2010; Huseynov dan Klamm, 2012) memakai tarif pajak efektif sebagai proksi dari tingkat agresivitas pajak. Tarif pajak efektif yang rendah menggambarkan tingkat agresivitas pajak yang tinggi dan demikian juga sebaliknya. Untuk mendapatkan ukuran tingkat agresivitas pajak yang semakin meningkat, variabel 
tingkat agresivitas pajak dalam penelitian ini diukur mengalikan tarif pajak efektif dengan -1 (Lanis dan Richardson, 2010:67).Tingkat agresivitas pajak diukur dengan:

$$
\text { Effective Tax Rate }=\frac{\text { Income Tax Expense }}{\text { Pre Tax Income }} \times-1
$$

Tabel 1. Statistik Deskriptif

Statistics

\begin{tabular}{|c|c|c|c|c|}
\hline & & Likuiditas & Leverage & Manajemen Laba \\
\hline \multirow[t]{2}{*}{$\mathrm{N}$} & Valid & 148 & 148 & 148 \\
\hline & Missing & 0 & 0 & 0 \\
\hline Mean & & 2,0772 & 0,4532 & 0,0142 \\
\hline Median & & 1,6886 & 0,4471 & $-0,0013$ \\
\hline Std. Deviation & & 1,2535 & 0,1855 & 0,1094 \\
\hline Range & & 6,5036 & 0,8412 & 0,8112 \\
\hline Minimum & & 0,4818 & 0,0642 & $-0,3957$ \\
\hline \multirow[t]{2}{*}{ Maximum } & & 6,9854 & 0,9054 & 0,4155 \\
\hline & & $\begin{array}{l}\text { Komisaris } \\
\text { Independen }\end{array}$ & $\begin{array}{c}\text { Ukuran } \\
\text { Perusahaan }\end{array}$ & Agresivitas Pajak \\
\hline \multirow[t]{2}{*}{$\mathrm{N}$} & Valid & 148 & 148 & 148 \\
\hline & Missing & 0 & 0 & 0 \\
\hline Mean & & 0,382 & 1,3989 & $-0,253$ \\
\hline Median & & 0,3333 & 1,3957 & $-0,2546$ \\
\hline Std. Deviation & & 0,0947 & 0,0338 & 0,066 \\
\hline Range & & 0,4667 & 0,1587 & 0,4691 \\
\hline Minimum & & 0,2 & 1,3227 & $-0,4693$ \\
\hline Maximum & & 0,6667 & 1,4814 & $-0,0002$ \\
\hline
\end{tabular}

Variabel likuiditas memiliki rata-rata sebesar 2,0772 dengan median 1,6886. Penyimpangan baku untuk likuiditas perusahaan adalah 1,2535. Nilai tertinggi untuk likuiditas perusahaan adalah 6,9854 dan yang terendah adalah 0,4818. Perbedaan antara nilai tertinggi dan terendah adalah sebesar 6,5036. Hal ini menunjukkan bahwa perusahaan manufaktur yang terdaftar di Bursa Efek Indonesia memiliki kemampuan yang cukup baik untuk memenuhi kewajiban jangka pendeknya dengan aset lancar yang dimiliki perusahaan.

Leverage memiliki rata-rata sebesar 0,4532 dengan nilai tengah sebesar 0.4471 . Nilai deviasi standar adalah sebesar 0,1855. Selisih nilai tertinggi dan terendah adalah 0.8412 . Nilai tertinggi adalah 0,9054 dan nilai terendah adalah 0,0642. Dari analisa diatas dapat disimpulkan bahwa rata-rata perusahaan manufaktur memiliki kewajiban yang harus diselesaikan dengan 45\% dari seluruh sumber daya yang dikendalikan oleh perusahaan.

Manajemen laba memiliki rata-rata sebesar 0,0142 dengan nilai tengah sebesar -0,0013. Range manajemen laba adalah sebesar 0,8112 dengan nilai tertinggi adalah 0,4155 dan 
nilai terendah adalah -0,3957. Angka positif menunjukkan bahwa perusahaan melakukan maksimalisasi laba sedangkan angka negatif menunjukkan perusahaan meminimalisasi laba. Secara umum perusahaan manufaktur memaksimalisasi laba. Hal ini dapat dilihat dari rata-rata positif seperti uraian diatas.

Rata-rata proporsi komisaris independen adalah 0,3820. Nilai rata-rata ini telah memenuhi ketentuan minimum proporsi komisaris independen, yaitu 30\%. Akan tetapi, nilai minimum proporsi komisaris independen dalam model ini adalah 0,2. Hasil statistik ini menunjukkan bahwa terdapat beberapa emiten yang belum mematuhi ketentuan BEI terkait proporsi komisaris independen. Adapun besar simpangan baku variabel ini adalah 0,0947 dan mediannya 0,3333. Range pengamatan adalah 0,4667 dengan nilai tertinggi 0,6667 .

Mean dari ukuran perusahaan adalah 1,3989. Apabila dikonversikan ke Rupiah, maka rata-rata total aset perusahaan manufaktur di Bursa Efek Indonesia adalah 1,1 trilyun. Deviasi standar ukuran perusahaan adalah 0,0338 dan mediannya adalah 13957. Nilai tertinggi ukuran perusahaan adalah 1,4814 dan nilai terendahnya adalah 1,3227, sehingga range pengukurannya adalah 0,1587 .

Mean variabel tingkat agresivitas pajak adalah -0,2530 dengan median sebesar 0,2546 . Angka ini yang menandakan bahwa rata-rata tarif pajak efektif perusahaan terbuka di Indonesia telah sesuai dengan tarif pajak yang berlaku berdasarkan undang-undang, yaitu 25\%. Nilai deviasi standar tingkat agresivitas pajak adalah 0,0660. Selisih nilai tertinggi dan nilai terendah pengamatan adalah 0,4691. Nilai tertinggi observasi adalah 0,0002 dan nilai terendah adalah $-0,4693$.

\section{HASIL DAN PEMBAHASAN}

Pengujian Asumsi Klasik. Alat statistik yang digunakan dalam penelitian ini adalah ordinary least square, oleh karena itu asumsi klasik yang mendasari teknik ini perlu diuji agar kesimpulan yang diambil tepat secara statistik. Asumsi klasik yang perlu diuji meliputi normalitas, multikolinearitas, heteroskedastisitas, dan autokorelasi.

Pertama. Normalitas. Uji normalitas adalah pengujian yang dilakukan untuk mengetahui apakah data dalam sebuah model regresi variabel bebas, variabel terikat atau keduanya berdistribusi normal atau tidak. Model regresi yang baik seharusnya memiliki distribusi data yang normal. Dalam penelitian ini, digunakan metode one sample KolmogorovSmirnov Test dengan nilai signifikansi sebesar 5\%.

Apabila nilai signifikansi lebih besar atau sama dengan 0,05 maka Ho tidak ditolak atau dengan kata lain data terdistribusi secara normal. Sebaliknya apabila nilai signifikansi lebih kecil dari 0,05 maka Ho ditolak atau dengan kata lain data tersebut tidak terdistribusi secara normal.

Data dalam model penelitian ini awalnya tidak normal. Hal itu dapat dilihat pada Tabel 2 Setelah dilakukan pengujian outlier, pengujian normalitas dilakukan kembali. Adapun pengujian normalitas dilakukan dengan menggunakan Kolmogorov-Smirnov test dan outlier didefinisikan sebagai observasi yang menyebabkan standardized residual berada di luar rentang -2,56 sampai dengan 2,56. 
Tabel 2. One-Sample Kolmogorov-Smirnov Test

\begin{tabular}{llr}
\hline & & Unstandardized Residual \\
\hline Normal Parameters & & 170 \\
& Mean &, 0000000 \\
& Std. Deviation &, 09537841 \\
Most Extreme Differences & Absolute &, 137 \\
& Positive &, 126 \\
Kolmogorov-Smirnov Z & Negative &,- 137 \\
Asymp. Sig. (2-tailed) & & 1,782 \\
\hline a. Test distribution is Normal. & &, 003 \\
b. Calculated from data. & &
\end{tabular}

Berdasarkan hasil pengujian outlier, diperoleh 22 data outlier yang perlu dibuang. Pembuangan outlier ini menyebabkan jumlah sampel yang awalnya 170 data berkurang menjadi 148 data. Pengujian normalitas setelah pembuangan outlier yang tampak pada Tabel 3 memperlihatkan bahwa residual model penelitian terdistribusi normal. Fakta ini terlihat dari nilai asymp. sig. (2-tailed) sebesar 0,088 lebih besar dari batas 0,05.

Tabel 3. One-Sample Kolmogorov-Smirnov Test

\begin{tabular}{llr}
\hline & & Unstandardized Residual \\
\hline $\mathrm{N}$ & & 148 \\
Normal Parameters & Mean &, 000000000000 \\
& Std. &, 0618488099603 \\
Most Extreme Differences & Deviation &, 103 \\
& Absolute &, 103 \\
& Positive &,- 102 \\
Kolmogorov-Smirnov Z & Negative & 1,250 \\
Asymp. Sig. (2-tailed) & &, 088 \\
\hline a. Test distribution is Normal. & & \\
b. Calculated from data. & &
\end{tabular}

Kedua. Multikolinearitas. Uji multikolinieritas digunakan untuk mengetahui apakah pada model regresi ditemukan adanya korelasi antar variabel bebas. Jika variabel bebas saling berkorelasi, maka variabel bebas tersebut ini tidak ortogonal. Variabel ortogonal adalah variabel bebas yang nilai korelasi antar sesama variabel bebas sama dengan nol. Jika terjadi korelasi, maka dinamakan terdapat problem multikolinieritas. Model regresi yang baik seharusnya tidak memiliki korelasi di antara variabel bebasnya. Jika terjadi multikolinieritas, maka salah satu variabel bebasnya harus dikeluarkan dari model regresi. Dalam penelitian ini uji multikolinieritas dilakukan dengan menggunakan nilai Variance 
Inflation Factor (VIF) dan nilai tolerance untuk melihat ada atau tidaknya korelasi di antara variabel bebas. Untuk menentukan ada atau tidaknya multikolinieritas nilai VIF harus di bawah 10 dan nilai tolerance harus di atas 0,1. Jika kedua hal tersebut dapat terpenuhi, maka tidak terjadi masalah multikolinieritas untuk masing-masing variabel bebas yang diuji.

Berdasarkan output SPSS pada Tabel 4 terlihat bahwa nilai VIF likuiditas adalah sebesar 1,990 dengan tolerance 0,502. Nilai VIF leverage adalah 2,020 dengan tolerance 0,495 . Nilai VIF manajemen laba adalah 1,073 dengan tolerance 0,932 . Nilai VIF proporsi komisaris independen adalah 1,053 dengan tolerance 0,949. Nilai VIF ukuran perusahaan adalah 1,069 dengan tolerance 0,936. Oleh karena seluruh variabel menunjukkan nilai VIF yang masih kurang dari 10 dan nilai tolerance yang lebih besar dari 0,1, maka dapat diambil kesimpulan bahwa model penelitian terbebas dari gangguan multikolinearitas.

Tabel 4. Hasil Uji Multikolinieritas

\begin{tabular}{|c|c|c|c|}
\hline \multirow{2}{*}{\multicolumn{2}{|c|}{ Model }} & \multicolumn{2}{|c|}{ Collinearity Statistics } \\
\hline & & \multirow[t]{2}{*}{ Tolerance } & \multirow[t]{2}{*}{ VIF } \\
\hline 1 & (Constant) & & \\
\hline & Likuiditas & ,502 & 1,990 \\
\hline & Leverage & 495 & 2,020 \\
\hline & Manajemen Laba & 932 & 1,073 \\
\hline & Komisaris Independen & 949 & 1,053 \\
\hline & Ukuran Perusahaan & ,936 & 1,069 \\
\hline
\end{tabular}

Ketiga. Heteroskedastisitas. Uji heteroskedastisitas digunakan untuk mengetahui apakah dalam sebuah model regresi terjadi ketidaksamaan variance dan residual dari satu pengamatan ke pengamatan yang lain. Jika variance dan residual dari satu pengamatan ke pengamatan lain tetap maka disebut homokedastisitas. Jika berbeda maka dinamakan heteroskedastisitas. Model regresi dikatakan baik jika tidak terjadi heteroskedastisitas. Terdapat beberapa pengujian yang biasanya digunakan yaitu Uji Spearman's rho, Uji Glejser, Uji Park dan melihat pola grafik scatterplot.

Dalam penelitian ini uji heteroskedastisitas menggunakan uji Glejser. Untuk menentukan ada atau tidaknya heteroskedastisitas dapat dilihat dari nilai signifikansinya. Model regresi yang bebas dari masalah heteroskedastisitas adalah yang mempunyai nilai signifikan lebih dari 0,05. Apabila variabel independen mempunyai nilai signifikan lebih dari 0,05, maka tidak terjadi heteroskedastisitas. Sebaliknya, apabila variabel independen mempunyai nilai signifikan lebih dari 0,05, maka terjadi heteroskedastisitas.

Output pengujian heteroskedastisitas dengan Gletjser test menunjukkan bahwa model penelitian terbebas dari gangguan heteroskedastisitas. Hal ini tampak dari variabel likuiditas memiliki nilai sig. sebesar 0,2833, variabel leverage memiliki nilai sig. sebesar 0,2729 , variabel manajemen laba memiliki nilai sig. sebesar 0,8988 , variabel proporsi komisaris independen memiliki nilai sig. sebesar 0,0655 dan variabel ukuran perusahaan memiliki nilai sig. sebesar 0,0503. Tabel 5 menunjukkan hasil uji Gletjser yang menunjukkan seluruh independent variable memiliki nilai sig. lebih besar dari ambang batas 0,05 . 
Tabel 5. Hasil Uji Hipotesis Statistik

Coefficients $^{\mathrm{a}}$

\begin{tabular}{|c|c|c|c|c|c|c|}
\hline & \multirow[t]{2}{*}{ Model } & \multicolumn{2}{|c|}{$\begin{array}{c}\text { Unstandardized } \\
\text { Coefficients }\end{array}$} & \multirow{2}{*}{$\begin{array}{c}\begin{array}{c}\text { Standardized } \\
\text { Coefficients }\end{array} \\
\text { Beta }\end{array}$} & \multirow[t]{2}{*}{$\mathrm{t}$} & \multirow{2}{*}{ Sig. } \\
\hline & & $\mathrm{B}$ & Std. Error & & & \\
\hline \multirow[t]{6}{*}{1} & (Constant) & ,311 & ,152 & & 2,052 & ,0420 \\
\hline & Likuiditas &,- 004 & ,004 &,- 121 & $-1,077$ & ,2833 \\
\hline & Leverage & ,030 & ,027 & ,124 & 1,101 & ,2729 \\
\hline & Manajemen Laba & ,004 & ,034 & ,010 & ,127 & 8988 \\
\hline & Komisaris Independen & ,072 & ,039 & 151 & 1,856 & 0655 \\
\hline & Ukuran Perusahaan &,- 215 & 109 &,- 162 & $-1,974$ & ,0503 \\
\hline
\end{tabular}

a. Dependent Variable: ABSRES

Keempat. Autokorelasi. Uji autokorelasi digunakan untuk mengetahui apakah dalam sebuah model regresi ada korelasi antara kesalahan pengganggu pada periode $t$ dengan kesalahan penganggu pada periode t-1 (sebelumnya). Jika terjadi korelasi maka dinamakan ada problem autokorelasi. Autokorelasi muncul karena pengamatan yang berurutan sepanjang waktu berkaitan satu sama lainnya. Masalah ini timbul karena residual (kesalahan penganggu) tidak bebas dari satu pengamatan ke pengamatan lainnya. Masalah residual sering ditemukan pada data runtut waktu (time series) karena "gangguan” pada satu individu atau kelompok cenderung mempengaruhi "gangguan” pada individu atau kelompok yang sama pada periode berikutnya. Model regresi yang baik adalah yang bebas autokorelasi. Uji autokorelasi dalam penelitian ini menggunakan uji Durbin-Watson (uji DW). Model regresi dikatakan tidak terdapat gejala autokorelasi jika nilai Durbin-Watson berada di antara dU dan 4-dU.

Pada Tabel 6 terlihat bahwa nilai Durbin-Watson hitung sebesar 2,145. Berdasarkan tabel Durbin-Watson untuk alpha sebesar 5\% dan 5 variabel independen $(k=5)$, pada sampel sebanyak 148 data $(n=148)$ diperoleh nilai $d u$ sebesar 1,8016 dan nilai $4-d U$ adalah sebesar 2,1984. Dengan demikian berdasarkan uji Durbin - Watson diperoleh Durbin - Watson hitung berada di antara $d U$ dan $(4-\mathrm{du})$ sehingga model penelitian telah terbebas dari gangguan autokorelasi.

Tabel 6. Hasil Uji Autokorelasi

Model Summary

\begin{tabular}{ll}
\hline Model & \multicolumn{1}{c}{ Durbin-Watson } \\
\hline 1 & 2.145 \\
\hline a. Predictors: (Constant), UKURAN Perusahaan, & \\
Manajemen Laba, Komisaris Independen, Likuiditas, & \\
Leverage & \\
b. Dependent Variable: AGRESIVITAS PAJAK
\end{tabular}


Penelitian ini bertujuan untuk menentukan apakah terdapat pengaruh likuiditas, leverage, manajemen laba, proporsi komisaris independen, dan ukuran perusahaan secara simultan terhadap tingkat agresivitas pajak. Pengaruh simultan tersebut mencerminkan apakah persamaan regresi yang dihasilkan dapat digunakan untuk peramalan.

Kelima. Uji F. Uji F digunakan untuk menguji kelayakan model regresi. Dasar pengambilan keputusannya adalah jika nilai signifikansi lebih kecil dari 0,05 maka model regresi layak untuk digunakan. Sebaliknya, jika nilai signifikansi lebih besar atau sama dengan 0,05 maka model regresi tidak layak untuk digunakan.

Tabel 7 menunjukkan hasil uji F yang dilakukan terhadap model penelitian. Nilai pada kolom sig. sebesar 0,002 jelas lebih kecil daripada 0,05. Oleh karena itu, dapat diambil kesimpulan bahwa hipotesis alternative diterima, yaitu likuiditas, leverage, manajemen laba, proporsi komisaris independen dan ukuran perusahaan berpengaruh secara simultan terhadap tingkat agresivitas pajak perusahaan. Penerimaan hipotesis ini mencerminkan bahwa persamaan regresi yang terbentuk dapat digunakan untuk peramalan.

Tabel 7. Hasil Uji Model Penelitian

\begin{tabular}{|c|c|c|c|c|c|}
\hline \multicolumn{6}{|c|}{ ANOVA $^{a}$} \\
\hline Model & Sum of Squares & $\mathrm{df}$ & Mean Square & $\mathrm{F}$ & Sig. \\
\hline 1 Regression & ,079 & 5 & ,016 & $\overline{3,989}$ &, $002^{b}$ \\
\hline Residual & 562 & 142 & ,004 & & \\
\hline Total & ,641 & 147 & & & \\
\hline
\end{tabular}

a. Dependent Variable: Agresivitas Pajak

b. Predictors: (Constant), Ukuran Perusahaan, Manajemen Laba, Komisaris Independen, Likuiditas, Leverage

Keenam. Hasil Regresi Berganda. Uji t (Tabel 5) digunakan untuk menguji besarnya pengaruh variabel bebas terhadap variabel terikat. Pengujian dilakukan dengan menggunakan nilai signifikansi sebesar 0,05. Penentuan keputusan untuk menerima atau menolak hipotesis dirumuskan sebagai berikut: Jika nilai signifikansi lebih kecil dari 0,05 maka Ho ditolak dan Ha tidak ditolak, dengan kata lain dapat disimpulkan bahwa variabel bebas tersebut secara individu mempunyai pengaruh yang signifikan terhadap variabel terikat. Sebaliknya jika nilai signifikansi lebih besar atau sama dengan 0,05 maka Ho tidak ditolak dan Ha ditolak, dengan kata lain dapat disimpulkan bahwa variabel bebas tersebut secara individu tidak mempunyai pengaruh yang signifikan terhadap variabel terikat.

Tabel 5 menunjukkan koefisien likuiditas, leverage, manajemen laba, proporsi komisaris independen dan ukuran perusahaan dalam persamaan regresi. Dari output tersebut, terlihat bahwa persamaan regresi yang terbentuk adalah:

$\mathrm{Y}=-0,967-0,001 \mathrm{X} 1+0,017 \mathrm{X} 2+0,134 \mathrm{X} 3-0,006 \mathrm{X} 4+0,506 \mathrm{X} 5$

Dengan:

$\mathrm{Y}=$ tingkat agresivitas pajak (-tarif pajak efektif); X1 = liquiditas; X2 = leverage; $\mathrm{X} 3$ = manajemen laba; X4 = proporsi komisaris independent; X5 = ukuran preusan. 
Konstanta persamaan sebesar -0,967 menunjukkan bahwa jika nilai likuiditas, leverage, manajemen laba, proporsi komisaris independen dan ukuran perusahaan adalah 0, nilai tingkat agresivitas pajak adalah -0,967. Nilai koefisien likuiditas sebesar -0,001 menunjukkan bahwa kenaikan nilai likuiditas 1 satuan dengan variabel-variabel lain konstan akan menurunkan nilai agresivitas pajak sebesar -0,001 satuan. Angka koefisien 0,017 pada variabel leverage berarti setiap kenaikan leverage 1 satuan dengan variabelvariabel lainnya konstan akan menaikan agresivitas pajak sebesar 0,017 satuan. Manajemen laba memiliki koefisien sebesar 0,134 menunjukkan bahwa setiap kenaikan manajemen laba 1 satuan dengan variabel-variabel lain konstan akan menaikan agresivitas pajak sebesar 0,134 satuan. Koefisien proporsi komisaris independen sebesar -0,006 menunjukkan bahwa setiap kenaikan 1 satuan proporsi komisaris independen akan menurunkan agresivitas pajak sebesar 0,006 satuan. Ukuran perusahaan memiliki angka koefisien sebesar 0,506 yang berarti bahwa setiap kenaikan ukuran perusahaan 1 satuan akan menaikan agresivitas pajak sebesar 0,506 satuan.

Hasil uji t pada tabel 5 menunjukkan bahwa variabel likuiditas memiliki signifikansi sebesar 0,927. Oleh karena nilai signifikansi variabel likuiditas lebih besar dari 0,05 maka dapat disimpulkan bahwa Ho tidak ditolak dan Ha ditolak. Hal ini menunjukkan bahwa likuiditas perusahaan tidak berpengaruh signifikan terhadap tingkat agresivitas pajak perusahaan. Hasil penelitian ini sesuai dengan penelitian yang dilakukan oleh Krisnata Dwi Suyanto dan Supramono (2012) bahwa tidak ada pengaruh antara likuiditas perusahan terhadap tingkat agresivitas pajak perusahaan. Sebaliknya, penelitian ini tidak konsisten dengan hasil penelitian yang dilakukan oleh Jason W. Stanfield (2012) yang menemukan bahwa perusahaan dengan tingkat likuiditas rendah kemungkinan tidak akan mematuhi peraturan perpajakan dan berpengaruh pada perilaku penghindaran pajak sehingga menurunkan tingkat agresivitas pajak perusahaan. Tidak signifikannya hubungan likuiditas perusahaan dan tingkat agresivitas pajak dapat disebabkan karena tingkat likuiditas pada perusahaan manufaktur relatif sama. Hal ini dapat terlihat dari analisa statistik deskriptif yang menunjukkan bahwa nilai deviasi standar sebesar 1,2535 lebih kecil dari rata-rata likuiditas perusahaan manufaktur yaitu sebesar 2,0772. Nilai deviasi standar yang lebih rendah dari nilai rata-rata dapat mengindikasikan bahwa tingkat likuiditas perusahaan manufaktur relatif sama.

Berdasarkan hasil uji t pada Tabel 5. variabel leverage memiliki signifikansi sebesar 0,675. Nilai signifikansi ini lebih besar dari 0,05. Hal ini berarti Ho tidak ditolak dan Ha ditolak. Dengan demikian dapat disimpulkan bahwa leverage perusahaan tidak berpengaruh signifikan terhadap tingkat agresivitas pajak perusahaan. Dari hasil tersebut dapat diketahui bahwa perusahaan tidak memanfaatkan hutang untuk melakukan penghindaran pajak. Meskipun berdasarkan ketentuan Pasal 6 ayat (1) huruf a UU Nomor 36 tahun 2008 perusahaan yang memiliki utang yang tinggi akan memperolah insentif pajak berupa potongan atas bunga pinjaman. Hasil penelitian ini tidak sesuai dengan penelitian Krisnata Dwi Suyanto dan Supramono (2012) yang menemukan bahwa leverage berpengaruh signifikan terhadap tingkat agresivitas pajak perusahaan. Meskipun hasil penelitian ini tidak sesuai dengan penelitian Dwi Suyanto dan Supramono (2012), tetapi hasil penelitian ini konsisten dengan penelitian yang dilakukan oleh Richardson dan Lanis (2007)yang menemukan bahwa leverage tidak menunjukkan adanya pengaruh yang signifikan terhadap agresivitas pajak perusahaan. 
Hasil uji t pada tabel 5 menunjukkan bahwa variabel manajemen laba memiliki nilai signifikansi sebesar 0,007. Nilai signifikansi variabel manajemen laba sebesar 0,007 ini lebih kecil dari 0,05. Nilai tersebut menunjukkan bahwa Ho ditolak dan Ha tidak ditolak sehingga dapat disimpulkan bahwa manajemen laba berpengaruh signifikan terhadap tingkat agresivitas pajak perusahaan. Dari hasil analisa statistik deskriptif diketahui bahwa selama periode pengamatan perusahaaan-perusahaan manufaktur tidak secara konsisten memiliki kecenderungan untuk menaikan laba. Terlihat dari hasil statistik deskriptif bahwa nilai standar deviasi lebih besar dibandingkan dengan nilai rata-rata manajemen laba perusahaan manufaktur. Hal ini dapat dijelaskan bahwa income increasing dilakukan perusahaan untuk tetap menjaga indikator kinerja perusahaan dan menekan tarif pajak efektif perusahaan sesuai dengan ketentuan perundangan perpajakan yang berlaku sebesar $25 \%$ dari laba bersih sebelum beban pajak penghasilan. Faktor lainnya yang dapat menjelaskan kejadian tersebut adalah pada periode pengamatan perusahaan manufaktur memperoleh laba yang menurun dari periode-periode sebelumnya. Sesuai dengan ketentuan perundangan perpajakan bahwa semakin besar penghasilan bersih sebelum pajak maka semakin besar pula beban pajak yang harus ditanggung oleh perusahaan. Hasil penelitian ini tidak mendukung penelitian oleh Lee dan Swenson (2010) yang menyatakan bahwa efek perpajakan tidak dipengaruhi secara signifikan oleh perataan laba terutama di negara-negara Asia. Meskipun demikian, hasil penelitian ini senada dengan temuan Krisnata Dwi Suyanto dan Supramono (2010) bahwa manajemen laba berpengaruh signifikan terhadap tingkat agresivitas pajak perusahaan.

Hasil uji t pada table 5 menunjukkan bahwa nilai signifikansi variabel proporsi komisaris independen lebih besar dari 0,05, yaitu sebesar 0,913. Hal ini menunjukkan bahwa Ho tidak ditolak dan Ha ditolak. Kesimpulan yang dapat diperoleh dari hasil tersebut adalah proporsi komisaris independen tidak berpengaruh signifikan terhadap tingkat agresivitas pajak. Hasil penelitian ini menunjukkan adanya indikasi bahwa dewan komisaris independen dari luar perusahaan yang merupakan bagian dari dewan komisaris perusahaan tidak melakukan fungsi pengawasan dengan baik terhadap manajemen. Pengawasan yang semakin besar oleh dewan komisaris independen diharapkan akan membuat manajemen semakin berhati-hati dalam mengambil keputusan, terutama yang berkaitan dengan perpajakan, dan meningkatkan transaparansi perusahaan. Dengan rata-rata proporsi komisaris independen sebesar 38,20\% menunjukkan bahwa proprosi komisaris independen tersebut tidak signifikan mempengaruhi manajemen dalam hal agresivitas pajak. Hal ini juga dapat berarti bahwa dewan komisaris independen tidak secara proaktif mendorong manajemen untuk mematuhi peraturan perundangan perpajakan yang berlaku sehingga meminimalkan terjadinya penghindaran pajak. Hasil ini sesuai dengan penelitian yang dilakukan oleh Nuralifmida Ayu Annisa dan Lulus Kurniasih (2012) yang menemukan bahwa kenaikan persentase proporsi dewan komisaris independen terhadap jumlah dewan komisaris secara keseluruhan tidak signifikan mempengaruhi kebijakan tax avoidance. Hasil penelitian yang berbeda dalam penelitian yang dilakukan oleh Krisnata Dwi Suyanto dan Supramono (2010) yaitu semakin besar proprosi komisaris independen maka perilaku agresif terhadap perpajakan yang dilakukan manajemen akan berkurang secara signifikan. Senada dengan temuan Krisnata Dwi Suyanto dan Supramono (2010), hasil penelitian Fama dan Jensen (1983) dalam Wulandari (2005) menemukan bahwa kehadiran komisaris independen dapat mendorong 
dilakukannya pengawasan secara profesional terhadap manajemen. Pengawasan yang optimal oleh para komisaris independen akan mengurangi kecurangan-kecurangan pajak yang dilakukan oleh perusahaan.

Hasil uji t pada Tabel 5 menunjukkan bahwa variabel ukuran perusahaan memiliki signifikansi sebesar 0,002. Nilai signifikansi ini lebih kecil dari 0,05. Hal ini menunjukkan bahwa Ho ditolak dan Ha tidak ditolak. Dengan demikian dapat disimpulkan bahwa ukuran perusahaan berpengaruh signifikan terhadap tingkat agresivitas pajak perusahaan. Hal ini sesuai dengan hasil penelitian Hsieh (2012) bahwa ukuran perusahaan berpengaruh negatif dan signifikan terhadap Effective Tax Rate perusahaan. Dalam penelitian tersebut, Shieh (2012) mengungkapkan bahwa perusahaan dengan ukuran yang lebih besar memperoleh keuntungan political power sehingga lebih agresif terhadap pajak dibandingkan dengan perusahaan yang berukuran lebih kecil. Berbeda dengan temuan Xing Liu dan Shujun Cao (2007) yang menyatakan bahwa Firm Size tidak memiliki dampak yang signifikan terhadap agresivitas pajak perusahaan yang diukur dengan Effective Tax Rate. Meskipun demikian, Xing Liu dan Shujun Cao (2007) juga menemukan bahwa perusahaan dengan ukuran lebih besar cenderung memiliki political power dan memperoleh keuntungan darinya dengan mempengaruhi regulasi terhadap bidang perpajakan sehingga tidak secara langsung memiliki dampak yang signifikan terhadap agresivitas pajak perusahaan.

Tujuh. Uji Koefisien Korelasi dan Uji Determinasi Ganda (R dan Adjusted R Square). Uji koefisien korelasi (R) bertujuan untuk mengetahui bagaimana hubungan antara variabel bebas dengan variabel terikat. Nilai koefisien determinasi adalah antara nol dan satu. Jika nilai $\mathrm{R}$ mendekati satu, maka dapat dikatakan hubungan antara variabel bebas dan variabel terikat adalah kuat. Jika nilai R mendekati nol, maka dapat dikatakan hubungan antara variabel bebas dan variabel terikat adalah lemah.

Uji determinasi ganda (Adjusted R Square) bertujuan untuk mengetahui seberapa besar variasi dari variabel bebas dapat menjelaskan variabel terikat. Nilai Adjusted $\mathrm{R}$ Square ini dipakai karena dapat naik atau turun apabila satu variabel independen berpengaruh secara signifikan ditambahkan ke dalam model. Hal ini dikarenakan nilai Adjusted R Square tidak seperti nilai R Square yang sudah pasti berubah hanya dengan memasukkan variabel independen tanpa mempedulikan apakah berpengaruh secara signifikan atau tidak.

Jika nilai Adjusted R Square kecil, maka kemampuan variabel-variabel bebas dalam menjelaskan variabel terikat sangatlah terbatas. Jika nilai Adjusted $\mathrm{R}$ Square mendekati satu, maka variabel bebas memberikan hampir semua informasi yang dibutuhkan untuk menjelaskan variabel terikat. Kenyataannya nilai Adjusted R Square dapat bernilai negatif, walaupun yang dikehendaki bernilai positif. Apabila terdapat nilai Adjusted R Square yang bernilai negatif maka nilai negatif tersebut dianggap bernilai nol.

Nilai R dari model penelitian ini adalah 0,351 seperti pada Tabel 8 hal ini menunjukkan bahwa antara variabel bebas dan variabel terikat tidak terlalu kuat. Nilai adjusted $R$ square dari model penelitian, terlihat bahwa nilai adjusted $R$ square adalah 0,092. Artinya, sebesar 9,2\% variasi dalam tingkat agresivitas pajak dapat dijelaskan oleh variabel likuiditas, leverage, manajemen laba, proporsi komisaris independen dan 
ukuran perusahaan, sedangkan 90,8\% sisanya dijelaskan oleh variabel-variabel lainnya di luar model penelitian ini.

Tabel 8. Model Summary ${ }^{\mathrm{b}}$

\begin{tabular}{|c|c|c|c|c|}
\hline Model & $\mathrm{R}$ & R Square & Adjusted R Square & $\begin{array}{l}\text { Std. Error of the } \\
\text { Estimate }\end{array}$ \\
\hline 1 &, $351^{\mathrm{a}}$ & .123 & .092 & .0629283 \\
\hline
\end{tabular}

\section{PENUTUP}

Simpulan. Berdasarkan pembahasan yang telah dilakukan, diperoleh beberapa kesimpulan penelitian. Kesimpulan pertama adalah likuiditas perusahaan tidak berpengaruh signifikan terhadap agresivitas pajak. Dengan demikian H1 ditolak. Hasil penelitian ini konsisten dengan penelitian yang dilakukan oleh Krisnata Dwi Suyanto dan Supramono (2012). Berbeda dengan penelitian yang dilakukan oleh Jason W. Stanfield (2012) yang menemukan bahwa likuiditas berpengaruh terhadap tingkat agresivitas pajak secara signifikan.

Kesimpulan kedua adalah leverage perusahaan tidak berpengaruh signifikan terhadap agresivitas pajak. Dengan demikian H2 ditolak. Hasil penelitian ini konsisten dengan penelitian yang dilakukan oleh Richardson dan Lanis (2007). Hasil penelitian ini tidak konsisten dengan penelitian yang dilakukan oleh Krisnata Dwi Suyanto dan Supramono (2012).

Kesimpulan ketiga adalah manajemen laba berpengaruh signifikan terhadap agresivitas pajak. Dengan demikian H3 tidak ditolak. Hasil penelitian ini tidak mendukung penelitian oleh Lee dan Swenson (2010) yang menyatakan bahwa efek perpajakan tidak dipengaruhi secara signifikan oleh perataan laba terutama di negara-negara Asia. Meskipun demikian, hasil penelitian ini senada dengan temuan Krisnata Dwi Suyanto dan Supramono (2010) bahwa manajemen laba berpengaruh signifikan terhadap tingkat agresivitas pajak perusahaan.

Kesimpulan keempat adalah proporsi komisaris independen tidak berpengaruh secara signifikan terhadap tingkat agresivitas pajak. Dengan demikian H4 ditolak. Hasil ini sesuai dengan penelitian yang dilakukan oleh Nuralifmida Ayu Annisa dan Lulus Kurniasih (2012) yang menemukan bahwa kenaikan persentase proporsi dewan komisaris independen terhadap jumlah dewan komisaris secara keseluruhan tidak signifikan mempengaruhi kebijakan tax avoidance. Hasil penelitian yang berbeda dalam penelitian yang dilakukan oleh Krisnata Dwi Suyanto dan Supramono (2010) yaitu semakin besar proprosi komisaris independen maka perilaku agresif terhadap perpajakan yang dilakukan manajemen akan berkurang secara signifikan.

Kesimpulan kelima adalah ukuran perusahaan berpengaruh secara signifikan terhadap agresivitas pajak perusahaan. Dengan demikian H5 tidak ditolak. Hal ini sesuai dengan hasil penelitian Hsieh (2012) bahwa ukuran perusahaan berpengaruh negatif dan 
signifikan terhadap Effective Tax Rate perusahaan. Berbeda dengan temuan Xing Liu dan Shujun Cao (2007) yang menyatakan bahwa Firm Size tidak memiliki dampak yang signifikan terhadap agresivitas pajak perusahaan yang diukur dengan Effective Tax Rate.

\section{DAFTAR RUJUKAN}

Annisa, Nurlifmida Ayu dan Kurniasih, Lulus. (2012) "Pengaruh corporate governance terhadap tax avoidance”. Jurnal Akuntansi dan Auditing. 8(2). hal 123-136

Balakrishnan et al. (2012) Does tax aggressiveness reduce corporate transparency?. University of Pennsylvania

Barata, Atep Adya. (2010) Ketentuan umum dan tata cara perpajakan: pengetahuan dasar perpajakan. Jakarta: Artha Bakti Nagara

Belkaoui, Ahmed Riahi. (2004) Accounting theory. $5^{\text {th }}$ Edition. London: Thomsom Learning

Bursa Efek Indonesia. (2012) IDX fact book 2012. Jakarta: Bursa Efek Indonesia. . (2011) IDX fact book 2011. Jakarta: Bursa Efek Indonesia.

Cooper, Donald R dan Pamela Schindler. (2011) Business research methods. Eleventh edition. New York: McGraw-Hill Higher Education

Dunbar et al. (2011) What do measures of tax aggresiveness measure?. National Tax Association Proceedings from the 103rd Annual Conference in Chicago

Ghozali, Imam. (2011) Aplikasi analisis multivariate dengan program IBM SPSS 19. Edisi lima. Semarang: Badan Penerbit Universitas Diponegoro

Hsieh, Yao-Chih. (2012) "New evidence on determinants of corporate effective tax rates". African Journal of Business Management. 6(3). hal 1177-1180

Kementerian Keuangan. (2013) Data - data Pokok Anggaran dan Belanja Negara Tahun 2013. Jakarta: Kementrian Keuangan.

Keputusan Direksi PT Bursa Efek Jakarta Nomor Kep-305/BEJ/07-2004 tentang Peraturan Nomor I-A tentang Pencatatan Saham dan Efek Bersifat Ekuitas Selain Saham yang Diterbitkan oleh Perusahaan Tercatat

Kieso, Donald E., Jerry J. Weygandt dan Terry P. Warfield. (2011) Accounting Principles. $10^{\text {th }}$ Edition. Hoboken: John Wiley \& Sons, Inc

Lanis, Roman dan Grant Richardson. (2007) "Determinants of the variability in corporate effective tax rates and tax reform: evidence from Australia”. Journal of Accounting and Public Policy. 26(6). hal 689-704

. (2011) "The effect of board of director composition on corporate tax aggressiveness". Journal of Accounting and Public Policy. 30(1). hal 50-70

Lee, Namryoung dan Swenson, Charles. (2011) "Earnings Management through discretionary expenditures in the U.S., Canada, and Asia”. International Business Research. 4(2). hal 257-266

Liu, Xing dan Shujun Cao. (2007) "Determinants of corporate effective tax rates : evidence from listed companies in China”, The Chinese Economy. 40(6). hal 49-67

Peraturan Nomor IX.I.5 Lampiran Keputusan Ketua BAPEPAM Kep-41/PM/2003 tentang Pembentukan dan Pedoman Pelaksanaan Kerja Komite Audit 
Richardson, Grant dan Lanis, Roman. (2007) "Determinant of the variability in corporate effective tax rates and tax reform: evidance from Australia". Journal of Accounting and Public Policy. 26. hal 689-704

Rodriguez, Elena Fernandez dan Arias, Antonio Martinez. (2012) Do business characteristics determine an effective tax rate?. The Chinese Economy. 45. hal 60-83

Sekaran, Uma dan Roger Bougie. (2010) Research method for business: a skill building approach. Fifth edition. New Jersey: John Wiley and Sons

Stanfield, Jason W. (2011) "Cash liquidity, holdings, and performance as determinants of corporate tax avoidance”. Disertasi. Purdue University

Subramanyam et al. (2009) Financial statement analysis. Tenth Edition. London: MCGraw Hill.

Suyanto, Krisnata Dwi dan Supramono. (2012) "Likuiditas, leverage, komisris independen, dan manajemen laba terhadap agresivitas pajak perusahaan”. Jurnal Keuangan dan Perbankan. 16. hal 167-177

Undang-Undang No. 28 Tahun 2007 tentang Perubahan Ketiga Atas Undang-Undang Nomor 6 Tahun 1983 Tentang Ketentuan Umum dan Tata Cara Perpajakan

Undang-Undang No. 36 Tahun 2008 tentang Perubahan Keempat atas Undang-Undang Nomor 7 Tahun 1983 Tentang Pajak Penghasilan

Wang, Yiqun. (2012) Competition and tax evasion: a cross country study. Economic Analysis and Policy. 42(2). hal 189-208

Zimmerman, Jerold L. (1983) "Taxes and firm size”. Journal of Accounting and Economics. 5(1). hal. 119-149 